\title{
READ MY LIPS: ONSCREEN VISUAL ACOUSTICS IN ALFRED HITCHCOCK'S EARLY MOVIES
}

\author{
LEE MIS LABIOS: LA ACOUSTICA VISUAL DE LA PANTALLA \\ EN LAS PRIMERAS PELICULAS DE ALFRED HICHCOCK
}

FABIO L. VericAT

Universidad Complutense de Madrid

flverica@ucm.es

Fecha de recepción: 08-09-2021

Fecha de aceptación: 28-10-2021

\section{Abstract}

This essay will cover some of Alfred Hitchcock's early silent movies up to and including Blackmail (1929), of which he filmed both a silent and a sound version simultaneously. Hitchcock's success with sound was directly linked to his training in silent technique. Silent movies actually allowed him to explore how they were capable of sound. This essay will consider how silent movies were able to induce an acoustic experience without the aid of extra-diegetic practices that added live - and sometimes gramophonic - soundtrack to films. What I am interested in is the aural effect of the visual experience of the screen alone. In the early days of cinema, the frame was silently read for all kind of sounds heard in the head of the spectator.

KEY WORDS: Alfred Hitchcock; Modernism; early cinema; silent movies; acoustics; visual literacy

\section{RESUMEN}

Este artículo trata sobre las películas mudas de Alfred Hitchcock hasta Blackmail (1929), de la que filmó simultáneamente una versión muda y otra sonora. Su habilidad 
para gestionar el sonido venía de su aprendizaje con técnicas del cine mudo. Las películas mudas, de hecho, le permitieron explorar como ya eran capaces de producir sonidos. Este artículo examina cómo las películas mudas podían inducir una experiencia acústica sin la ayuda de prácticas extradiegéticas que añadían bandas sonoras en vivo - a veces gramofónica - al film. Lo que a mí me interesa es el efecto aural solo de la pantalla. En los principios del cine, la pantalla era leída en silencio a modo de escuchar todo tipo de sonidos dentro de la cabeza del espectador.

Palabras Clave: Alfred Hitchcock; Modernismo; principios del cine; cine mudo; acústica; alfabetización visual

Even if it is now generally accepted that «we know that silent cinema was never actually silent — or hardly ever,» most of the attention paid to the sounds of silent cinema has focused on extra-diegetic practices that added live - and sometimes gramophonic soundtrack to film (KING, 1984: 2). ${ }^{1}$ These included music, but also sound effects and voices (of actors and/or of a lecturer). Such critical attention, however, has not considered how silent movies were able to induce an acoustic experience in the spectator without the help of such practices, but by the effect of the visual experience of the film alone. There have been suggestions that spectators were increasingly able to hear past the diegetic silence of early film's pure visuality by learning to tune in their 'inner' ear to the visual acoustics that peppered the filmstrip: somebody visibly playing an instrument, a dog in the act of barking, or people moving their lips when talking to each other.

This paper wants to explore how it is that the spectator could hear with her eyes by comparing it to the parallel experience of seeing onscreen writing in early film, such as intertitles or inserts. The fact is that when one makes visual contact with written language one inevitably triggers its phonemic content. It is what we commonly refer to as reading. The link between reading and hearing is such, that it takes a deliberate effort not to hear a word in our head when we make visual contact with it. It may be that we equally induce sound experience in areas of our visual experience other than when one comes across writing. When Alfred Hitchcock told Truffaut that «to describe a sound effect accurately, one has to imagine its equivalent in dialogue» (TRUFFAUT, 1984: 297), he was implying that speech is no mere sound effect. Speech is a very special acoustic experience, positioned at the junction between sound and text. This paper will consider the dual nature of speech by contrasting silent movies versus the 'talkie' with particular reference to Hitchcock's silent period up to and including his transition piece Blackmail (1929). It was simultaneously shot as a silent but also for sound, and was allegedly Britain's first 'talkie.' Blackmail's transition between silence and sound is exemplary of the underlying contiguity between the writing of the 'silents' and the speech of the 'talkies.'

\footnotetext{
King suggests that silent movies were often shot to music at the studio, though that very same music will not then have been heard at the theatres. He also explores the extent to which early film directors such as the French Abel Gance turned extra-diegetic sound practices into deliberate experimentalism. Gance scripted and scored such soundtracks so that they became intrinsic part of the film at their final performance even if they remained extraneous to it, namely because it was not the actual sound in synch with the recorded image.
} 
The sound of silent movies has received detailed attention from the likes of Rick Altman, whose Silent Film Sound is a tour-de-force in the cultural history of cinema in the first decade of the twentieth century. By drawing attention to the actual popular practice of displaying and viewing silent films in the American Nickelodeon, Altman unveils an unexpected cinematic experience within the larger context of audio-visual entertainment. Far from silent, in the first decade of the $20^{\text {th }}$-century, the experience of watching a film not only involved sharing an acoustic space filled with ballyhoo, but also the expectations of patrons to be entertained both through the eyes as well as the ears. The Nickelodeon «often featured attractions other than films, including illustrated song and vaudeville acts» (ALTMAN, 2004: 181). It is easy to conclude that, if only because of the direct or indirect acoustic pollution within the theatre, cinematic experience was never silent as such. More importantly, film itself soon started to claim its own elaborate sound practices such as sound effects, lecturers, voices behind the screen, recordings synchronized with the image, not to mention musical accompaniment.

In the beginnings of film spectatorship, and as preparation for the exhibition of a new movie, theatre proprietors would look through the film to find appropriate moments to add sound effects which would further add to the enjoyment of prospective patrons. An example of such onscreen «sound cues» (ALTMAN, 2004: 214) would be having somebody playing a trumpet onscreen, which would elicit having a musician actually play it from behind the screen in the theatre. Though originally unintentional, movies were increasingly shot with an eye to facilitate such live acoustic performances; that is, to give ample and legitimate opportunities for theatre proprietors to acoustically make the most of the moving image. When it came to adding live dialogue to a movie by actors standing behind the screen, «it was permissible only if the lips were moving» (ALTMAN, 2004: 172-73), so that film making began to favour the close-up.

If only in this sense, early film history is very much about sound. So much so that the plot of silent movies often revolved around it. As Altman puts it, «the act of listening took on special importance in the American film industry toward the end of the ought's [...] [their] major innovation is its use of hearing to connect spaces and further the plot» (ALTMAN, 2004: 214). Thus, audiences were slowly trained into hearing sound from what was otherwise the diegetic silence of pure visuality; to do it, that is, in their own heads without the aid of an actual theatrical soundtrack: «Whether activated or not by exhibitors, the virtual sound tracks increasingly built into the period's films were now mentally accessible to audiences sensitized to sound» (ALTMAN, 2004: 216). The immediate effect was to turn the volume off as patrons learnt to hear the sounds in their heads - learnt, in other words, literally to read the images. And just as one needs to read aloud when one first learns to read written words, practice makes that articulation unnecessary. It eventually becomes 'silent.' It all underlines the obvious fact that as Isabelle Raynauld puts it in 'Dialogues in Early Silent Sound Screenplays,' «silent stories took place, intra— and extradiegetically, in a hearing world» (ABEL and ALTMAN, 2001: 69), and so there must be sound in them which the spectator naturally added in.

But perhaps the most significant visual «sound cue» in silent movies was on-screen writing in the form of titles, intertitles, the cut-in or inserts. Writing is essentially a 
visual sound system specifically geared to the production of speech sounds. Thus, onscreen writing in early films had its origins in extra-diegetic sound practices which it ultimately incorporated; the lecturer, who in the early days «simply called out the title of each film was soon taken over by lantern slides and then by the films themselves in the form of opening titles which is why intertitles were often subsequently called 'leaders'» (ALTMAN, 2004: 140). Writing in films was, in effect, a sound technique, and, as such, some saw it as a threat to the cinema's pure visuality.

As the avant-garde artist and film maker, Kenneth Macpherson, put it in a review of Alfred Hitchcock's first talkie, Blackmail, for Close Up in 1929: «the talkies we all go to see are using a crassly naïve and retrospective manner which differs with the cinema's genesis only in that spoken dialogue now illustrates the picture-text instead of pictures illustrating written text» (Donald, Friedberg and Marcus, 1998: 90). If the image was first made subservient to the narrative established by on-screen writing which the film at worst only 'illustrated,' the coming of sound, mainly as speech, only reinforced the textual grip over the film's image. The fear was that, as Hitchcock put it, film would be reduced to «photographs of people talking» (TRUFFAUT, 1984: 61). Thus, the move from silence to sound in film history was not really that. It was a transition from pre-existent sound practices (including on-screen writing such as intertitles) into fully synchronized speech. In fact, if synch sound technology had been finally perfected in 1927, it had been pursued all along from the very inception of the moving picture as in the synch craze of 1907-1909 (ALTMAN, 2004: 33). Sound and image need not be antithetical in the cinema, and though Macpherson began to see that, he remained crucially deaf in one aspect.

In praising the first British sound movie, Hitchcock's Blackmail, Kenneth Macpherson was actually trying to reconcile himself with the 'talkie.' He does so by expressing his admiration for Hitchcock's ability to handle sound as montage; what he calls, with the Russians very much in mind, acoustical montage. As he put it in the film magazine he edited, Close Up, in October 1929:

Take this instance from Blackmail, it is a good one. I said Mr Hitchcock would help his montage with a scream, which, in fact he did do. You remember Anny Ondra after the murder pacing the streets. You remember her obsession with the flung back trailing hand of the murdered artist. At the end of her trudging, when she must have been, incidentally, very exhausted, the sight of a sleeping beggar with outflung, trailing hand, brings forth a scream. There is an immediate cut to the screaming face of the old woman who finds the artist's murdered body. (DONALD, FRIEDBERG and MARCUS 90-91)

Macpherson goes on to say that this scene illustrates the rightful symbiosis between sound and film, but, crucially, that the cut of linking two scenes separated in space would not have been possible in 'silence.' «There would have to be three additional un-dramatic shots needful to continuity, but a sagging of the dramatic moment». It is odd that such a staunch defender of silent movies would come to commend Hitchcock's sound technique. But despite this concession to acoustic montage in the talkies, what Macpherson remains 
deaf to is the sound of silent movies. Crucially, he does not seem to have seen or know of the silent version of Blackmail. ${ }^{2}$

After the premier of The Jazz Singer in September 1928 in London, British International Pictures remained undecided whether Blackmail should be shot sound or silent. They opted for a talkie, but what it really amounted to was a silent movie with a sound reel attached to the end of the film — The Jazz Singer was itself only really a 'part talking' movie according to Kineweekly's new classification system as of May 1929. ${ }^{3}$ Instead, Hitchcock secretly filmed two versions - a silent and a full 'talkie' — rather than the part 'talkie' he had officially committed himself to completing to the film producers. A silent version of Blackmail was released after the sound version and was released in the counties where theatres were not yet wired for sound. It would seem Macpherson had not ventured out of London to see it.

In the silent Blackmail, Hitchcock resolves the sequence Macpherson refers to without the need of «three additional un-dramatic shots.» The scene is almost identical to the sound version, as is the movie as a whole. As Charles Barr explains, Hitchcock did shoot Blackmail twice because «to use a dupe negative for (parts of) either version would have meant a loss of visual quality in the prints struck from it,» yet, «in every case the two takes are too similar not to have been shot in quick succession» (BARR, 1983: 123). The difference between the two scenes in question is limited to the expressionist emphasis of the concierge's body language in the silent version. She has her back turned to the camera as she peers into the cubicle, yet shakes with outstretched hands as we presume she catches sight of the cadaver (frame 1). ${ }^{4}$

\section{Frame 1}

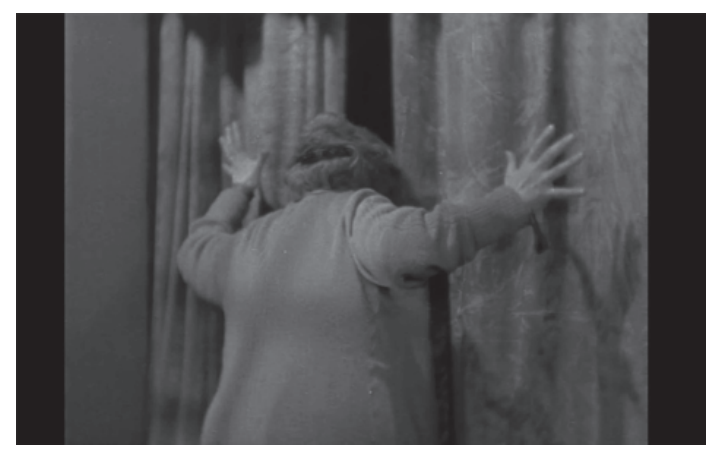

2 Kenneth Macpherson persistently defied sound up to 1930 with the making of his last movie, the silent Borderline (1930). As he noted in Close Up that November: «Eighteen months ago everybody was saying the silent film had reached perfection. It had no further to go. When in reality it had only reached the first stage in an intensive development. And oddly enough, it was not until the talkies had swept the silent film out of existence, that Borderline, perhaps the only really 'avant-garde' film ever made, came about» (Donald, Friedberg and Marcus, 1998: 90-91).

3 See Ryall, Tom (2003): «Blackmail,» British Film Institute Film Classics, vol.1, eds. Rob White and Edward Buscom, Nueva York, Taylor \& Francis.

4 All images reproduced in this article are in the public domain. 
We may not hear the scream, but we sure see it. The acoustic montage that Macpherson so admires in the sound version of Blackmail, stands surpassingly unaffected in the silent version. The scream remains the temporal link between the street (where the character played by Anny Ondra, Alice, comes across the sleeping homeless) and the artist's lodgings (where the corpse of the artist she has killed during her attempted rape the previous night lies). In the silent version, we hear the concierge's scream through her gestures alone, but which has an unexpected acoustic effect. The visual scream retroactively overlaps into the previous frame, «sounding» Alice's shock at catching sight of the sleeping tramp. In neither case is Alice's or the concierge's face shown. Yet, even if Macpherson praises Hitchcock's sound genius, it becomes apparent that such proficient acoustic montage is not of his own making alone. It both remains an acoustic effect implicit in the silent version but also within the general orthodoxy of sound practices developed throughout the silent era. Parallel editing (as well as jump cuts) was increasingly articulated around visual 'sound cues' as early as 1907, what Bernard Perron calls «transi-sound.» As he puts it: «the visualization of sound and listening played an important part in the suturing of space (particularly within the same place) and the systematization of parallel editing» (ABEL and ALTMAN, 2001: 84). In other words, sound - visual at that - lies at the heart of the development of montage techniques such as parallel editing before the arrival of the 'talkie.'

Unwittingly, Macpherson was crediting both sound and Hitchcock with a technique that was developed by the silent film in the first place. It is unsurprising that by Hitchcock's own admission, in Blackmail, he «utilized the technique of the talkies, but without sound» (TRUFFAUT, 1984: 64). He had been doing this all along in his silent movies. Hitchcock had been shooting silents as if they could talk, which is as good as saying what later he told Stage in 1936:

I try to tell my story so much so in pictures that if by any chance the sound apparatus broke down in the cinema, the audience would not fret and get restless because the pictorial action would still hold them! Sound is all right in its place, but it is silent picture training that counts today. (GOTTLIEB, 1997: 247)

Hitchcock did in principle agree to shoot Blackmail as a part-talking movie but planned to argue that only a couple of extra scenes would actually make it full talking; as if the movie despite having been shot silent was already only a short step away from sound. Quite literally both versions are an amalgam of silent and sound sequences, some dubbed, some silenced. It is not always clear which was originally what, hence impossible to decide which of the two movies is full talking, part-talking or silent anymore. What remains is the fact that Hitchcock thought some 'silent' sequences good enough for or to sound, which begs the question whether Hitchcock's silent movies were really all talkies with the sound turned off; silent only in that the spectator was relied on to provide the sound for themselves.

What remains interesting is that Macpherson's praise for sound in film, however, ultimately falls short of fully legitimizing the 'talkie.' He may show an uncharacteristic if magnanimous tolerance for sound, but not for speech. By dissociating sound from speech film criticism managed to find a way of reaching a compromise with the talkie, but that 
only went half way. Whichever way critics and filmmakers found to more or less reconcile themselves with sound, suspicion for speech remained generalized till the forties. As Elisabeth Weis and John Belton argue, the transition is that between classical and modern film theory, when eventually «speech is reintegrated into our notion of what the sound track is $[\ldots]$ No longer marginalized, sound and language share with the image an equal status» (Weis and Belton, 1985: 82, 145). Yet despite more recent attempts to restore the legitimacy of voice as sound in film, it becomes apparent how such reconciliation has been made at the expense of severing speech's complicity with writing.

In 1916, Hugo Münsterberg put it thus:

[Intertitles] appear sometimes as so-called «leaders» between the pictures, sometimes even thrown into the picture itself [...] In all these cases, the words themselves prescribe the line in which the attention must move and force the interest of the spectator toward the new goal. But such help by the writing on the wall is, after all, extraneous to the original character of the photoplay. (MÜNSTERBERG, 2002: 82)

The image is here presumed the autochthonous universal language of the photoplay, thus threatened by the «extraneous» status of writing. The implication is that whereas the image is universal, writing is necessarily limited to those who can read, let alone speak it. For a cinema proprietor this might amount to a very practical problem. As one such noted:

«[The movie is] great [...] simply splendid. Those who understand it think it's one of the best ever; but the trouble is, you see, that half of my regular patrons can't read English, and, for them, the picture is spoiled by the number of leaders. It's well acted, of course, but what they can't 'get' from the scenes they can't 'get' at all. But it's a great picture.» (ESENWEIN and LEEDS, 1919: 173)

This testimony appears in a 1919 film manual which adds: «Try, then, to write so as to make your story just as understandable and enjoyable for the Mexican labourer in Southern California as for the college professor in one of our Eastern cities» (ESENWEIN and LEEDS, 1919: 173). Try, that is, to write with images.

Hitchcock had originally made his way into the movies from what may only at first seem an unlikely job in the advertising section of W.T. Henley's Telegraph Works. It is here that he learnt his trade in the art of designing written soundbites in ironic counterpoint to illustrative images (figure 2).

Such experience no doubt helped him when he applied to Famous Players-Lasky for the job of intertitle designer. Thus, the prosaic designs for electrical cables, Hitchcock told Truffaut, «was a first step into cinema. It helped me get into the field» (TRUFFAUT, 1984: 26). By way of preparation Hitchcock had translated one of Lasky's projected novel adaptations into images that would appropriately decorate the intertitles he would be in charge of designing. "If the line read: 'George was leading a very fast life by this time,' I would draw a candle, with a flame at each end, just below the sentence. Very naïve» (TRUFFAUT, 1984: 27). The visual exploitation of writing increasingly became second nature to the young Hitchcock. By his own admission, when Hitchcock filmed The Lodger (1927), he «took a pure narrative and, for the first time, presented ideas in purely 
visual terms» (TRUFFAUT, 1984: 44). This movie was the result of his early admiration of German Expressionists such as Fritz Lang and F. W. Murnau, who had reduced to a minimum the onscreen presence of intertitles in their silent movies.

Figure 2

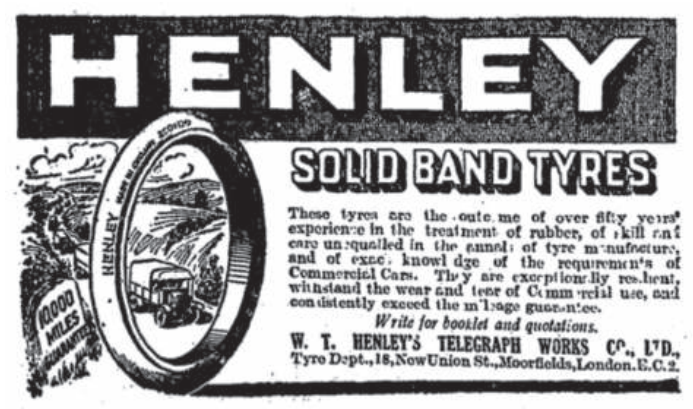

Hitchcock's first solo effort as art director of The Blackguard (Graham Cutts, 1925) was a UFA-Gainsborough co-production that took him to Berlin. It was the autumn of 1924 and German silent cinema was at its highest peak. Hitchcock witnessed first-hand Murnau at work on the sets of The Last Laugh (1925); it was, he recalled, «the prime example of expressing a story idea» as «told visually from beginning to end» (qtd. in MCGILLIGAN, 2003: 63). It was a way of dealing with a key problem in the narrative of silent movies: «in those days it was possible to completely alter the meaning of a script through the use of narrative titles and spoken titles» (TRUFFAUT, 1984: 27). However, even if Hitchcock praises Murnau's The Last Laugh for completely doing away with intertitles and measuring cinematic talent «by the ability to make a picture requiring the fewest titles», writing does not actually disappear from either of those films. Hitchcock actually shows how Murnau invented a synthetic language for «the street signs, the posters, the shop signs,» even if Truffaut reminds him that «some of the signs in Emil Jannings' house were in German, but those in the Grand Hotel were in this Esperanto» (TRUFFAUT, 1984: 31).

The fact was that doing away with the intertitle as something «extraneous to the original character of the photoplay,» did not in Hitchcock mean the end of writing. It meant, rather, its relocation within the screen; from the extra-diegetic 'leader' to within the frame as 'inserts.' Such 'inserts' are «letters, telegrams, newspaper paragraphs or personals, or any other matter inserted into the film during the progress of a scene, thus becoming practically part of that scene» (ESENWEIN and LEEDS, 1919: 21). Even Hugo Münsterberg, made allowances for the insert in the following terms: «The words of the telegram or of the signboard and even of the cutting from the newspaper are parts of the reality which the pictures are to show us and their meaning does not stand outside but within the pictorial story» (MÜNSTERBERG, 2002: 144). Writing is, after all, part of the visual environment we live in and could only be artificially ignored by the movies. 
In The Lodger writing features large from the very start; not, that is, as intertitles. The insert means that writing is read both by the spectator along with the characters within the frame, as we - at one point - join a newspaper editorial board in the reading of a Teletype message (frames 3 and 4 ).

Frame 3

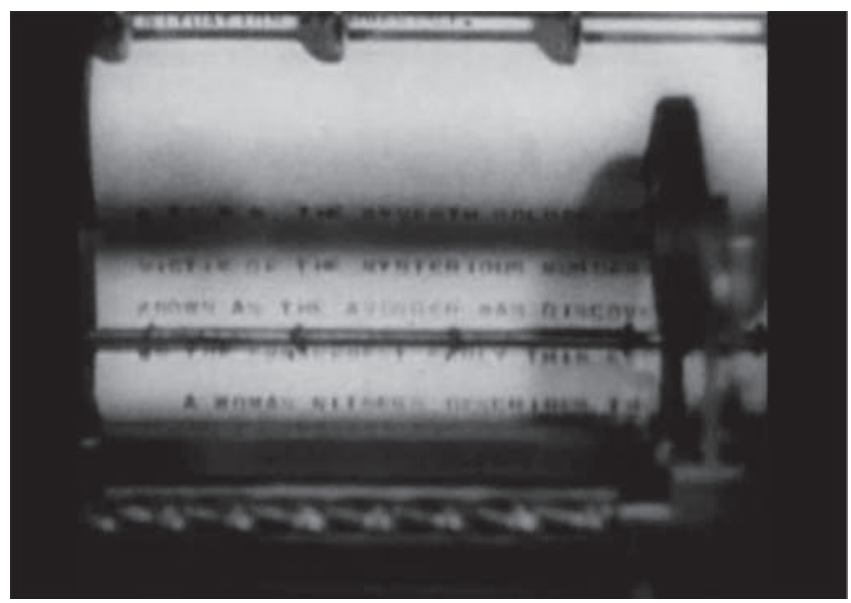

Frame 4

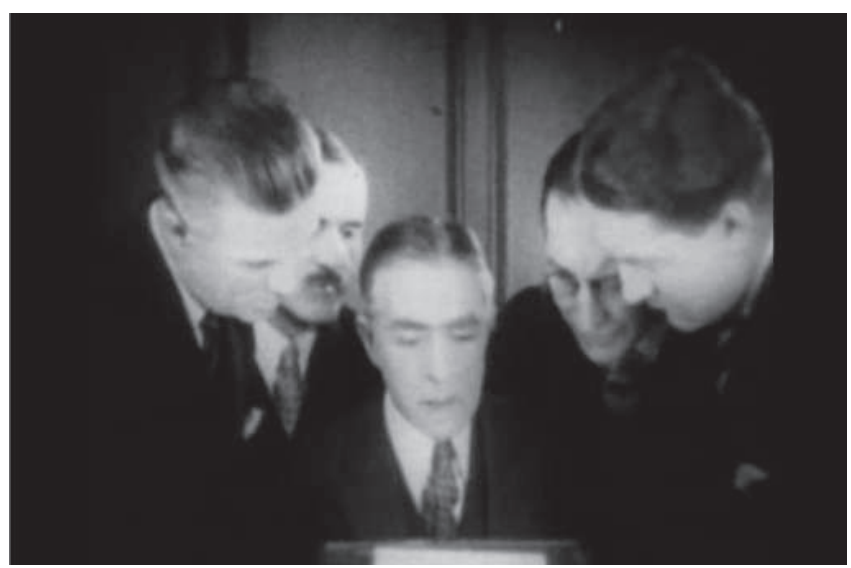

We learn about the contextual film narrative - about the serial killer the Avenger and his weakness for blondes - as we read the teletypes passing on the news, later as newspaper headlines being paraded on the streets, or other typographic media - billboards and the like — that invade the diegetic space of the movie with words. Street advertising naturalizes the 
presence of writing in-the-world, and Hitchcock was not one to pass over this opportunity. Such 'live' inserts compare inversely with the intertitles that do remain in the film but which are transformed, in turn, into visual rather than merely typographic experiences; mirroring, in some cases, the very electronic billboards one may have encountered in places such as Piccadilly Circus (frame 5). Hitchcock takes advantage of the visual legitimacy bestowed to writing by advertising which seamlessly populates the world of objects with words as much as, or simply as images.

\section{Frame 5}

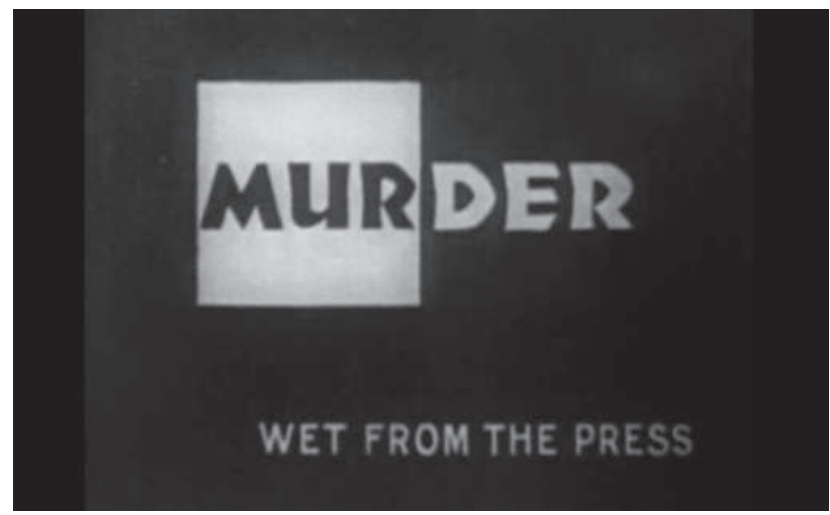

The resulting effect is one of blurring the diegetic line between 'inserts' and 'intertitles.' Word and image meet halfway.

Yet, and if we consider the opening frames of The Lodger again, what is more important is the link that Hitchcock established between this visual encounter with the word and its acoustic experience. Perhaps most explicit is the image of newspaper boys shouting the headlines they themselves wear (frames 6 and 7). Writing not only appears diegetically as something seen, but also as something read; that is, voiced if only because we are able to perceive the lips of the people move as they look at the words or read out loud the texts over the radio or over the phone, or inversely write down what they hear (frame 8). The technological mediation of voice (telephones, radio) that Hitchcock parades in the first few minutes of The Lodger reminds us that within the apparent silence of early cinema people can hear each other speak, which effectively turns such diegetic writing into a 'silent' soundtrack. 


\section{Frame 6}

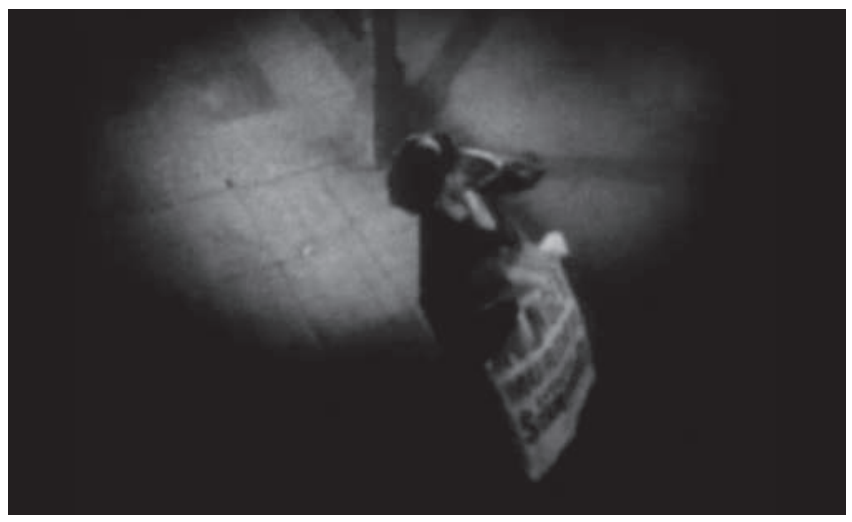

Frame 7

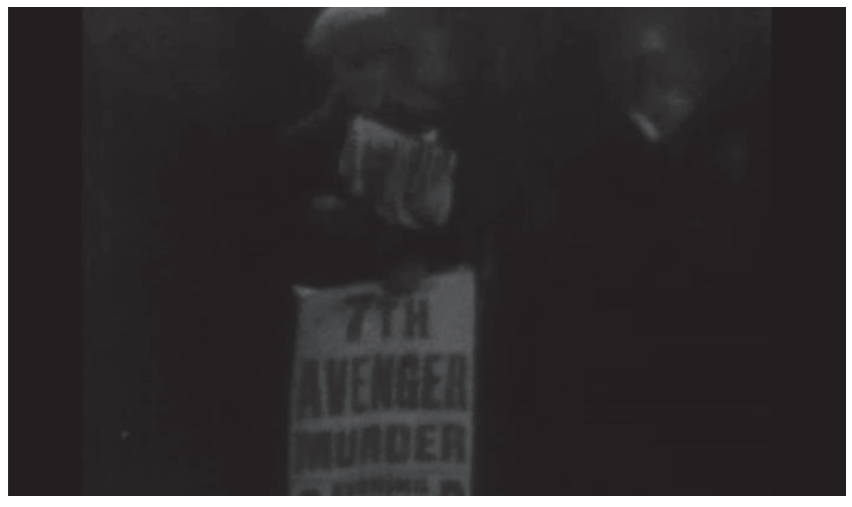

Frame 8

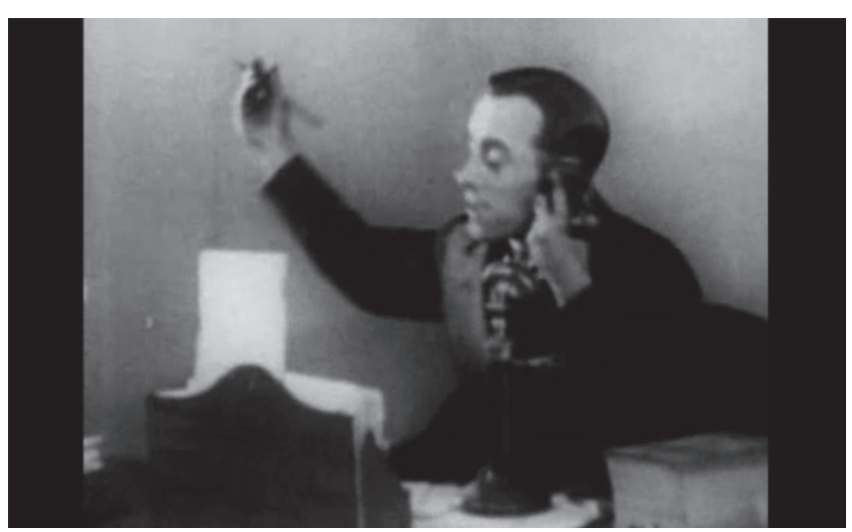

EPOS, XXXVII (2021) págs. 225-241 
It is no coincidence that Alexander Graham Bell first invented the telephone as a hearing aid aimed at teaching the deaf speak visually. By his own admission, Bell first conceived of the telephone as speaking through the telegraph; his greatest obsession, in following his father's footsteps, was the teaching of what he called 'visible speech. ${ }^{5}$ The telephone would teach the deaf to hear just as we - deaf to the silent movie's diegetic world of sound - are acoustically engaged through the presence of such visual cues within the frame; a constant reminder that sound is in the diegetic air. Hitchcock is quite deliberate about this strategy. As he told the News Chronicle in 1937, in Easy Virtue (ALFRED HITCHCOCK, 1928) there was this telephone scene where the hero proposes to the heroine. Hitchcock «wanted to put the whole conversation over by means of a dumb show produced through a third person: in this case the telephone operator who was listening in» (GOTTLIEB, 1997: 163-64). The conversation the operator hears within the film's diegetic space becomes written on her face. For Rick Altman, in early cinema «interest in dialogue spawned increasing fascination with faces - not just moving lips but also the facial expressions that give dialogue its depth. Repeatedly, talking pictures supporters called for actors to be brought closer to the camera» (ALTMAN, 2004: 166, 73). Hitchcock had already tried in 1924 such visual cues in The Lodger's introductory sequence (frames 9 and 10).

\section{Frame 9}

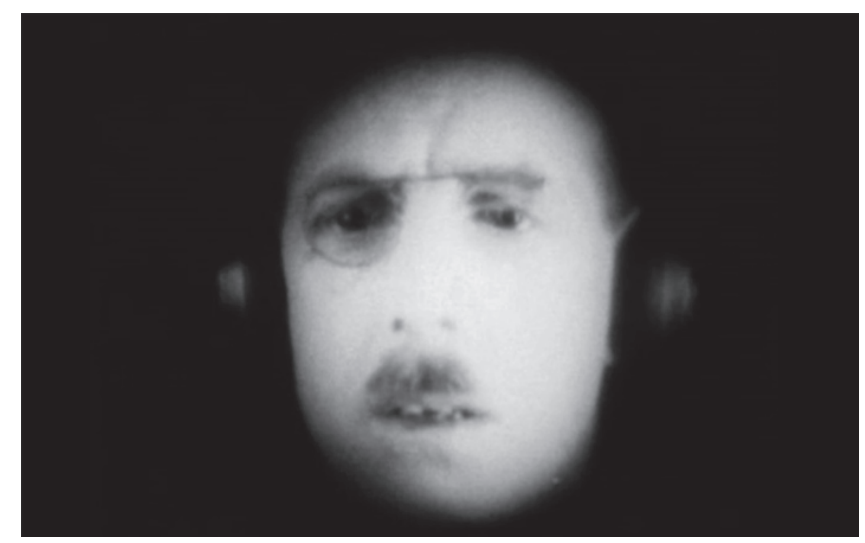

Notice how this supposedly dumb show foregrounds the aural experience of speech which is incarnated in the faces of those listening. It invites us to literally imagine speech sounds.

5 The Bells's technique of visible speech based on the position of the vocal apparatus was inscribed as a Universal Alphabet. It enabled the inscription of any sound and its replications through the vocal apparatus. If it universalized speech production, it also did so at the expense of reducing speech to the mechanics of vocal noise production thus divorced from writing. 


\section{Frame 10}

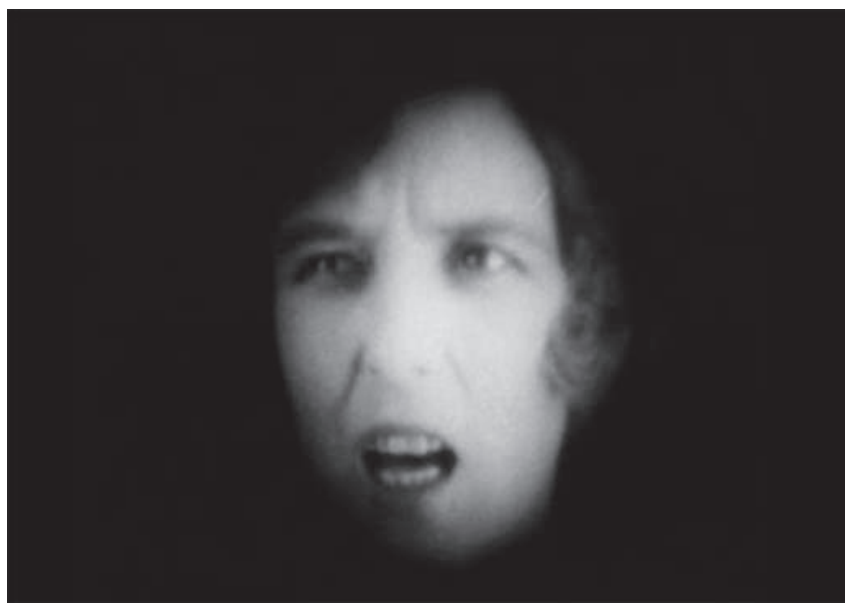

The aural depravation silent movies put us in only goes to show how much we already hear visually. Just like persons who have become deaf later in life, as Oliver Sacks puts it, «the world may remain full of sounds even though they are phantasmal» (Sacks, 1989: 6). The hearing of 'phantasmal voices' when one lip-reads is thus common to the postlingually deaf - but also to anyone who happens to decipher a conversation out of earshot by looking into the persons' lips. It follows, as Isabelle Raynauld argues, that it is «a misconception to consider 'silent' cinema as lacking sound» (ABEL and Altman, 2001: 71). She quite rightly concludes that «films produced before the talkies were nonetheless made for and by the hearing world.» But it is more than that. The point is that spectators of a silent movie legitimately constitute an audience. They are because silent movie goers were in a position to hear visually because they knew how the world sounded, just as the literate know how to enunciate writing. Visual hearing is, in fact, paradigmatic of ordinary alphabetic reading. There is no such thing as a silent reading even when one only reads to one-self. There is no such thing as silent movies either.

Take Hitchcock's last silent, The Manxman (1929). Truffaut comments that «at one moment [in The Manxman] the heroine says, 'I'm expecting a baby.' She articulates the phrase so clearly that one can read her lips. In fact, you dispensed with a title» (TRUFFAUT, 1984: 61). There is, however a better instance later on in the film, when the doctor comes downstairs having just assisted a birth to find two men waiting: the secret lover, who is the real father of the baby, and his best friend, the husband who 'thinks' is the father.

Here lip-reading also supplants the need for intertitles, but this time the act is more deliberate as the doctor has to repeat the phrase «Who is the father?» twice. The first time the phrase is unreadable - or should we say inaudible? - as the frame cuts out before the visual enunciation of the lips is complete. It raises the expectation for an intertitle that is not offered. It makes the repetition of the phrase by the actor, now in close up, an act 
of deliberate arrest of the intertitle with the required piece of explanatory dialogue (frame 11). Instead, we are redirected towards the aural experience of reading the image itself, that is, lip-reading the doctor's question: «Who is the father?» Of course, the repetition of the question by the doctor creates tragic-comic suspense as the identity of the father is precisely what is in question. He understandably presumes the father to be the husband, not the lover, and it is to him that he repeats the question, by clearly enunciating it in such a way that lip reading becomes unavoidable to us, the spectators thus turned into audience.

\section{Frame 11}

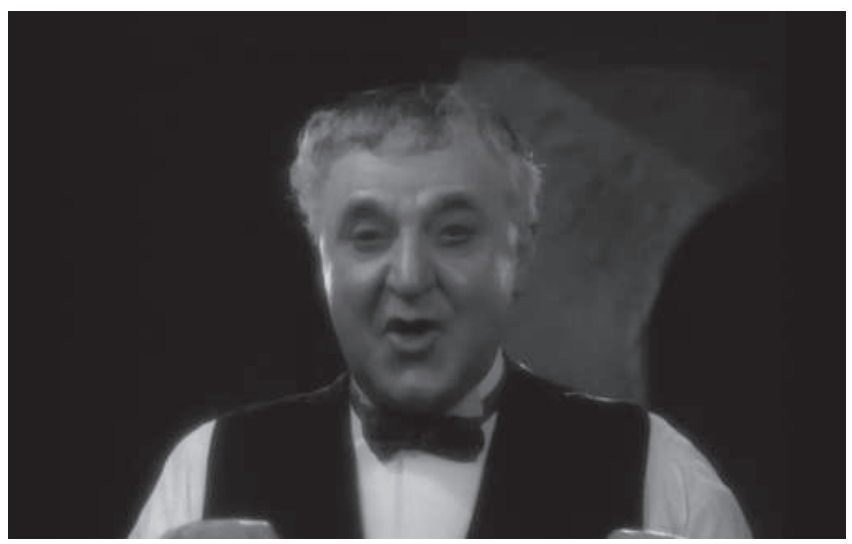

Hitchcock may have been exaggerating when he said that in the 'silent' days one could alter the plot by altering what the actors 'said' with the use of intertitles: «since the actor pretended to speak and the dialogue appeared on the screen right afterward, they could put whatever words into their mouths» (TRUFFAUT, 1984: 27). Isabelle Raynauld's research has in fact provided evidence that such practices were not the norm. In «Written Scenarios of Early French Cinema: Screenwriting Practices in the First Twenty Years,» she notes that silent film scenarios often scripted in full all the unheard spoken exchanges between characters, not just the intertitles and inserts (Raynauld, 1997: 260). ${ }^{6}$ So, just as scenarios increasingly gave a central narrative role to acoustic events (namely, speech) in silent movies, so, Raynauld tells us, «the lines to be spoken by the actors became an important part of the standard screenplay» (ABEL and Altman, 2001: 72) whether or not they appeared in the titles, even if they could not be heard. Sound movies are not much different in this respect. Much of the dialogue conforming the acoustic atmosphere of the scenes goes unheard in that it cannot be properly made out. It remains a background noise.

There is an interesting scene at the end of the opening sequence of the sound version of Blackmail. The scene shows policemen at the station getting ready to leave at the end

\footnotetext{
$6 \quad$ Also see Azlant, 1997: 228-256.
} 
of their shift but whose individual conversations and jokes are buried under the general hubbub of the crowd. For John Belton, ${ }^{7}$

the unheard jokes from which we (and certain characters) are excluded establish a certain relationship between us and the narrator, who suppresses information from us, using sound to excite our curiosity as to its content, using the desire for sound that is especially characteristic of the early years of the sound film and frustrating that desire by making the potential source of pleasure - a joke - inaudible. This works against the grain of «realistic» sound practice, which dictates that everything, especially human speech, must be audible. (BELTON, 1999: 242)

That may be, yet on attending to the scene one cannot escape an alternative feeling: that in «real» life one often does not hear all the words in conversations and that the punch line of a joke is often not dependent on understanding us such — but is actually the merry acceptance of not ever completely «getting it.» We may not hear the joke the policemen are telling each other, but we could — and do — legitimately laugh with them all the same. That is, 'audibility' may be something more than just hearing all the words. It suffices to recognize, though, that what we are hearing when people speak is no ordinary noise. It is a special kind of noise, speech, which because never clearly heard (accent, idiom, acoustics, and so on) has to be worked out, read into, as it were. Listening to speech is always a process of disambiguation into text which is never completely finalized. Audibility is thus always a question of degrees; of how acceptable that mental transcription from the sounds heard into text is something meaningful.

There is another scene when Frank, the policeman and Alice's fiancé, makes a call from a phone booth about the case of the murdered artist. Halfway through the perfectly audible conversation Frank closes the door. We can still see him through the glass door pane which frames him. When he turns his back to the camera a faint murmur testifies that he continues to speak. Here speech is pushed to the edge of noise, if only that, as it becomes seemingly unintelligible, we retain the ability to read speech into it almost past the point of audibility. We hear speech because we know that it is there, within the noise. In the silent version of Blackmail, the same scene shows Frank going into the telephone booth, but this time he immediately closes the door. It makes no difference because we cannot hear anyway. Yet the acoustic experience is announced as Joe visibly coughs just as he puts the receiver to his mouth and, then, begins to move his lips. It is as if he were sound testing the device with the cough, but also, and more importantly, checking our visual audition as we watch him from beyond the glass or the movie screen. (Testing, testing, testing. Cough, cough, cough.) Such auditory spectatorship flaunts the film as self-consciously silent yet very much aware of its capability to make us hear past the point of audibility. Just as the film briefly cuts from Frank to the shopkeeper - Alice's dad - straining to hear his phone conversation from behind the counter (frame 12), so are we reminded that silence is not absolute and that speech may be lurking just under the surface.

7 Also see Tom Gunning, «Doing for the Eye What the Phonograph Does for the Ear» in Abel and Altman, 2001: 18, and James Lastra, «Reading, Writing, and Representing Sound,» in Rick Altman, ed. (1992): Sound Theory, Sound Practice, London, Routledge, pp. 65-86. 
Frame 12

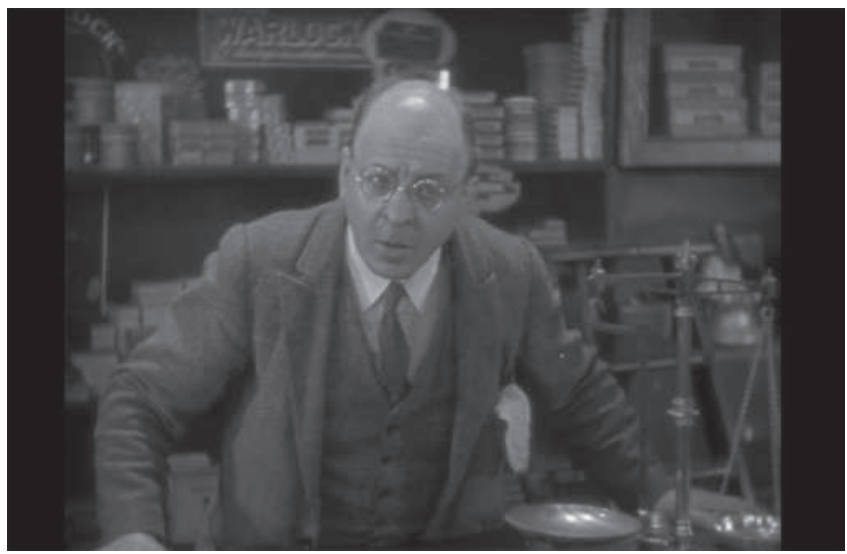

$* * *$

In Hitchcock's hands when speech is reduced to or is subdued by noise, it retains the promise of its textual redemption as language. In this he is quite deliberate. Others chose differently. Charlie Chaplin preferred rather to satirize speech turning it into irredeemable noise in the silent movie City Lights (1931). Already into the sound era, Chaplin's was an act of protest against the 'talkies,' which it announces with the subtitle: 'A Comedy Romance in Pantomime.' In its opening scene, the Tramp is rudely awakened from his silent - not sound - sleep by the inaugural speech of the City Mayor. His words literally are incomprehensible political babble as the soundtrack is a distorted recording of a voice only very distantly resembling speech. The presence of the microphone stands as a witness of sound technology; as an intruder and distorter of visual autonomy. If anything, speech is presented as something ideologically suspect always liable to expressing a political subtext.

At the height of the silent period, the screenwriter, title designer and author of Gentlemen Prefer Blondes (1925), Anita Loos, had also opted for speechlessness in film but for very different reasons. Loos puts text on a level with the image but at the expense of silencing its phonemes. As Laura Frost has put it recently, Loos inventive use of the intertitle «taught [people] to view words as images» but which ultimately defied the words' phonemic status focusing rather on their status as objects in themselves. One of her characters, Frost tells us, is introduced with a title by the name of 'Count Xerkzsxxv' followed by a note: «Those of you who read titles aloud, you can't pronounce the Count's name. You can only think it» (Frost, 2010: 298). It is reverse onomatopoeia, the word as ideogram of itself. In the titles she designed for The Mystery of the Flying Fish (John Emerson, 1916), for instance, the narrative jokes rely on visual word play as in the name of the opium addict detective Coke Ennyday who endures dancing fits, jumping compulsively up and down, after every shot of opium which the intertitle wittily describes at one point as «full of hop.» Yet, such tactics also earned her criticism for displacing the action from the visual frame onto the writing itself. Thus, the tension Loos creates between text and image, however innovative and daring, not only 
exacerbated the already prevalent caution about text on film but also squeezed the sound out of writing and ultimately out of the film. It may be a sign of Loos's experimental affiliations with literary Modernism, so argues Frost (2010: 307), and which she imports into the popular cinematic culture, yet they were also fated to disappear with the advent of sound.

Another middlebrow modernist and fellow intertitle designer, Alfred Hitchcock, did more than just survive the coming of sound but imported the visual acoustics of the silent movie seamlessly into the 'talkie.' He capitalized on the knowledge that film had never stopped talking even when, at best, it only seemed to be making vague noises. It might not be Literature, but his movies keep straining our ears for language.

\section{REFERENCES}

Abel, Richard, and Rick ALTMAN (2001): The Sounds of Early Cinema, Bloomington, Indiana University Press.

Altman, Rick (2004): Silent Film Sound, New York, Columbia University Press.

Azlant, Edward (1997): «Screenwriting for the Early Silent Film: Forgotten Pioneers, 1897-1911», Film History, 43.1, pp. 228-56.

Barr, Charles (1983): «Blackmail: Silent and Sound», Sight and Sound, 52.2, pp. 122-26.

Belton, John (1999): «Awkward Transitions: Hitchcock's Blackmail and the Dynamics of Early Film Sound», Musical Quarterly, 83.2, pp. 227-46.

Donald, JAmes, ANne FRIEDBERG, AND LaURA MARCUS (1998): Close up, 1927-1933: Cinema and Modernism, London, Cassell.

Esenwein, J. Berg, And Arthur LEedS (1919): Writing the Photoplay, Springfield, Mass., The Home correspondence School.

Frost, Laura (2010): «Blondes Have More Fun: Anita Loos and the Language of Silent Cinema», Modernism/modernity, 17.2, pp. 291-311.

GotTLIEB, Sidney (1997): Hitchcock on Hitchcock: Selected Writings and Interviews, Berkeley, University of California Press.

King, Norman (1984): «The Sound of the Silents», Screen, 25.3, pp. 2-15.

McGilligan, Patrick (2003): Alfred Hitchcock: A Life in Darkness and Light, Chichester, Wiley.

Metz, Christian (1980): «Aural Objects», Yale French Studies, 60, pp. 24-32.

Münsterberg, Hugo ([1916] 2002): The Photoplay: A Psychological Study and Other Writings, New York, Routledge.

Raynauld, Isabelle (1997): «Written Scenarios of Early French Cinema: Screenwriting Practices in the First Twenty Years», Film History, 9.3, pp. 257-68.

SaCKs, Oliver (1989): Seeing Voices: A Journey into the World of the Deaf, Berkeley, University of California Press.

Stewart, Garrett (1990): Reading Voices: Literature and the Phonotext, Berkeley, University of California Press.

Truffaut, FrançoIs (1984): Hitchcock, New York, Simon \& Schuster Paperbacks.

Weis, Elisabeth and John BELTON, EDS. (1985): Film Sound: Theory and Practice, New York, Columbia University Press. 